\title{
Submergence Tolerance in Rice: Review of Mechanism, Breeding and, Future Prospects
}

\author{
Yusuff Oladosu ${ }^{1}{ }^{D}$, Mohd Y. Rafii ${ }^{1,2, * \mathbb{D}}$, Fatai Arolu ${ }^{1}\left(\mathbb{D}\right.$, Samuel Chibuike Chukwu ${ }^{1}(\mathbb{D}$, \\ Ismaila Muhammad ${ }^{1}$, Isiaka Kareem ${ }^{3}$, Monsuru Adekunle Salisu ${ }^{4}(0)$ and Ibrahim Wasiu Arolu ${ }^{5}$ \\ 1 Institute of Tropical Agriculture and Food Security, Universiti Putra Malaysia (UPM), UPM, Serdang 43400, \\ Malaysia; oladosuy@gmail.com (Y.O.); talk2fatty01@gmail.com (F.A.); \\ chukwusamuel54@yahoo.com (S.C.C.); ismuha2000@gmail.com (I.M.) \\ 2 Department of Crop Science, Faculty of Agriculture, Universiti Putra Malaysia (UPM), UPM, \\ Serdang 43400, Malaysia \\ 3 Department of Agronomy, University of Ilorin, Nigeria, P.M.B., Ilorin 1515, Nigeria; \\ abdulkareemishaaq@gmail.com \\ 4 Department of Agriculture, Faculty Technical and Vocational, Sultan Idris Education University, \\ Tanjung Malim 35900, Perak, Malaysia; salisuadekunle@gmail.com \\ 5 Kaduna State University, Faculty of Agriculture, Crop Science Department, P.M.B., Kaduna 2339, Nigeria; \\ ibrahimarolu@gmail.com \\ * Correspondence: mrafii@upm.edu.my; Tel.: +60-3-8947-4825
}

Received: 13 January 2020; Accepted: 10 February 2020; Published: 21 February 2020

check for updates

\begin{abstract}
Flooding or submergence is one of the major environmental stressors affecting many man-made and natural ecosystems worldwide. The increase in the frequency and duration of heavy rainfall due to climate change has negatively affected plant growth and development, which eventually causes the death of plants if it persists for days. Most crops, especially rice, being a semi-aquatic plant, are greatly affected by flooding, leading to yield losses each year. Genetic variability in the plant response to flooding includes the quiescence scheme, which allows underwater endurance of a prolonged period, escape strategy through stem elongation, and alterations in plant architecture and metabolism. Investigating the mechanism for flooding survival in wild species and modern rice has yielded significant insight into developmental, physiological, and molecular strategies for submergence and waterlogging survival. Significant progress in the breeding of submergence tolerant rice varieties has been made during the last decade following the successful identification and mapping of a quantitative trait locus for submergence tolerance, designated as SUBMERGENCE 1 (SUB1) from the FR13A landrace. Using marker-assisted backcrossing, the SUB1 QTL (quantitative trait locus) has been incorporated into many elite varieties within a short time and with high precision as compared with conventional breeding methods. Despite the advancement in submergence tolerance, for future studies, there is a need for practical approaches exploring genome-wide association studies (GWA) and QTL in combination with specific tolerance traits, such as drought, salinity, disease and insect resistance.
\end{abstract}

Keywords: abiotic stress; submergence tolerance; waterlogging; crop improvement; Quantitative trait locus; marker-assisted selection

\section{Introduction}

The agro-ecosystem is significantly affected by flooding, which has been on a continuous intensification for the past few decades [1]. Flooding is undoubtedly the third most vital constraint for achieving high productivity, after heat and drought, that is affecting crop production. Seasonal and unseasonal crop damage due to the occurrence of severe flooding amounts to billions of dollars in 
yield losses annually. For example, as reported by Bailey-Serres et al. [2], in the United States, a 12-year study on losses of crop production revealed that flooding is the second threat after drought. It was reported that these two abiotic stresses (flooding and drought) accounted for a 70\% drop in harvest in 2011 alone. In that year, there were insurance payouts of over 3 billion USD due to flooding, with over 1.6 billion paid on soybean and maize. In Pakistan, over 4.45 billion USD worth was lost due to flooding in rice, cotton, and wheat in 2010 [3]. Similarly, an increase in summer rainfall causes water stagnation and flooding, with the event of economic consequences across Europe [4].

At the moment, one of the most flood-threatened crops is rice. About 30\% (700 million) of people living in abject poverty (i.e., daily income less than 1\$) in Asian countries reside in flood-prone rice cultivating regions of South Asia, with Nepal, Bangladesh, and India accounting for half of the above-stated figure. In Nepal, $15 \%$ of the total cultivated areas of 1.5 million hectare is affected by floods every year [5]. Similarly, out of 16.1 million hectares of rice-growing areas in India, 5.2 million are occasionally affected by flood, while in Bangladesh, 1.6 million hectares of rice field are periodically affected by flood, out of a total area of 2.65 million hectares dedicated to rice cultivation [6]. Other most vulnerable deltas include Ayeyerwaddy delta in Myanmar, Red River and Mekong deltas in Vietnam. According to Wassmann et al. [7], these deltas provided up to 70\% of total rice cultivation areas in these countries, and continuous flooding will greatly threaten their food security. In fact, over $35 \%$ of rice-growing areas, mostly in Africa and Asia, where food insecurity is predominant are prone to flooding [2]. Excessive flooding portends a major risk to human livelihood and it is also a major contributor to the vulnerability and poverty in marginalized rural populations. It was projected that flood-prone coastal region will experience an increase in rainfall pattern, especially in tropical and subtropical regions [8]. The increase in flooding regime associated with climate change and the necessity to step up the current agricultural yield potential by $70 \%$ remains a great challenge to feed the human population, which is expected to reach over nine billion by 2050 [9]. Therefore, the development of resilient crops to combat flooding is required to nip this problem in bud.

Anthropic and natural habitats are characterized by various hydrological regimes, where flooding occurrence varies in depth, extent, frequency, and seasonal incidence. Devastating hydrological regimes including the Amazon floodplain, coastal marshes, river floodplains, and rice-cultivated areas are characterized by complete submergence up to several meters deep [10]. The remarkable variation in flooding regimes in nature ranges from soil waterlogging for a few days to complete submergence that lasts for months [11]. Most dryland cereals, such as barley, maize, and wheat, are very sensitive to flooding, which can cause $20 \%$ to $40 \%$ or more in grain yield losses in irrigated and rainfed lowland, respectively [12]. The distribution and abundance of plant species adapted to flood-prone environments are determined by the evolutionary pressure based on the selection of advantageous traits of plants under the affected areas. Submergence or waterlogging adaptabilities are heightened by the development of either anatomic or metabolic traits [10]. These traits represent the source of genetic diversity, which can be exploited by plant breeding. Similarly, it acts in synergy to prove submergence tolerance in plants [6].

The major objective of the international community is to increase the current agricultural production to catch up with the anticipated growth in population. Based on this background, it is essential to adopt germplasm and develop better abiotic resistant cultivars that can withstand flooding. Achieving this objective was reflected in the development of submergence-tolerant rice varieties that survive floods, and were subsequently deployed to farmers' fields in flood-prone rice-cultivating areas. This was manifested through the International Rice Research Institute's (IRRI) initiation of a robust submergence tolerance breeding programme of modern rice varieties that were developed through marker-assisted selection from local landraces. Therefore, understanding the molecular, physiological, morphological, and developmental mechanisms that trigger flooding tolerance would enable the translation of survival strategies of rice flooding to other crops to stabilize crop yields. Hence, the purpose of this review is to provide current progress in submergence tolerance in rice, provide an 
overview of physiological mechanisms for plant survival, quantitative trait locus identification, and utilization for the development of flood-tolerant rice varieties.

\section{Plant Survival and Biophysical Constraints of Flooding and Submergence in the Rice Field}

Rice is an important crop that serves as a staple food for over 3.5 billion of the world's population and also serves as food security for many countries in Africa and Asia [13]. It is widely grown in varied environmental conditions, ranging from sea coasts to high altitudes. The major rice-growing areas are greatly affected by flooding, caused by river discharge, excessive rainwater accumulation, and tidal movements. Globally, one-third of rice-cultivated areas are deep-water and rainfed lowland ecosystems, which account for about 50 million hectares [14]. These areas are prone to frequent flooding, which could be attributed to poor drainage systems of the excessive rainwater during the rainy season. Rice has anaerobic tolerance, however, extreme flooding, either complete or partial submergence, may result in various environmental stressors. Hence, rice cultivars respond differently to the variations in the floodwater regime. Therefore, it can be concluded that a flood-tolerant cultivar at one location cannot be transferred to another location [15]. There are three categories of flooding that occur at different crop growth stages and varied durations, which are typical of rice growing agroecosystems (Figure 1).

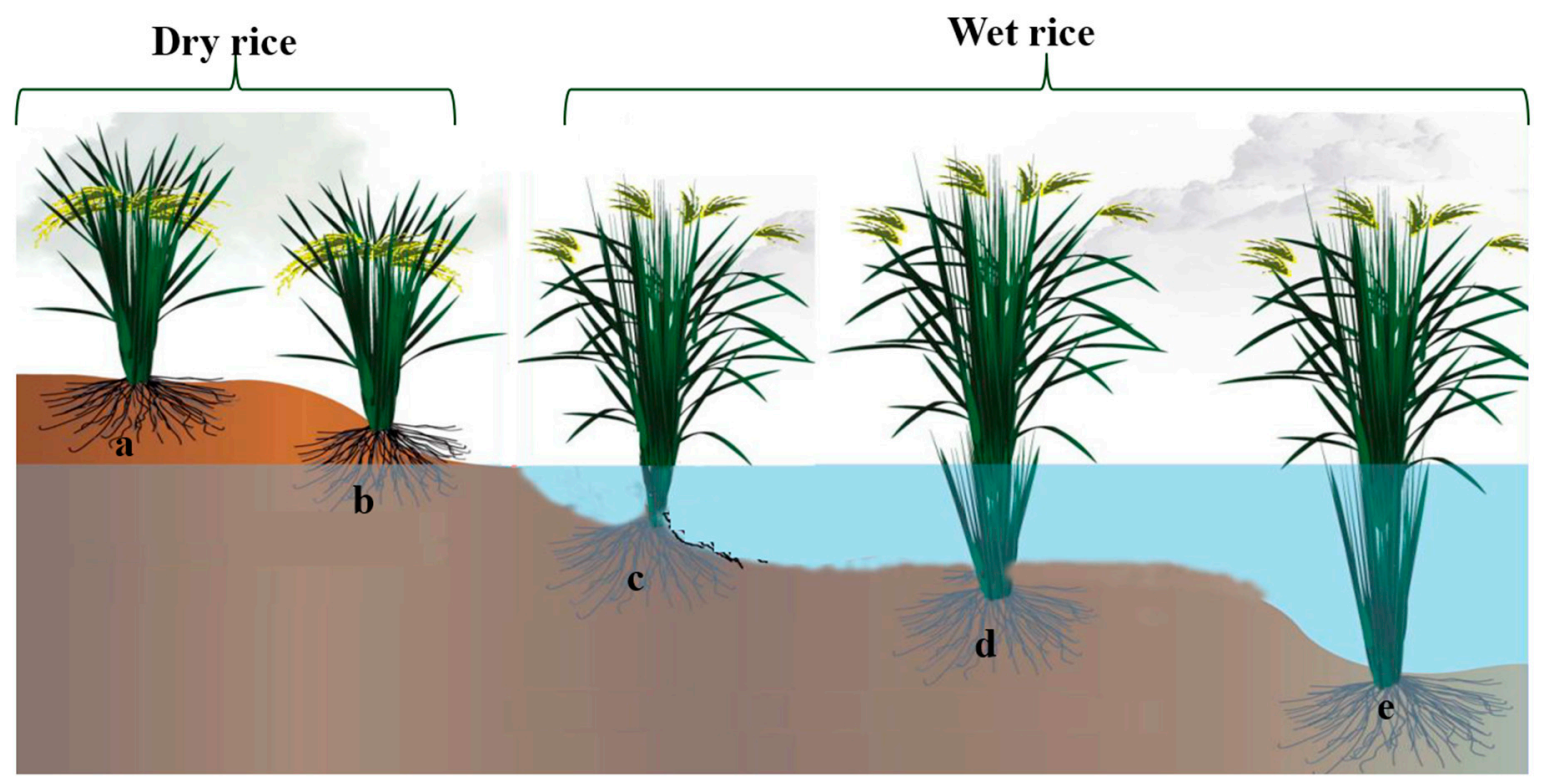

Figure 1. Scale of the rice-growing environment with respect to water level. (a) Upland rainfed; (b) lowland rainfed (groundwater); (c) flood recession irrigated; (d) flood-prone irrigated (rice field); (e) deep-water (floating rice).

Submergence during germination is the first category of floods, which is often referred to as anaerobic germination (AG). This condition commonly occurs in rainfed lowland ecosystems, which are characterized by heavy and sudden rainfall mostly associated after direct seeding cultural practices. Under this condition, rice seeds are submerged completely and suffer anoxia or hypoxia, which results in low or poor germination, poor crop establishment, and seedling death [16]. However, Angaji et al. [17] reported rice germplasm with the ability to germinate under anoxia and hypoxia conditions. Complete submergence during the vegetative growth stage is the second category which occurs either at seedling or tillering stage. Plants are completely flooded, ranging from days to weeks before the flooding recedes. Singh et al. [18] defined flooding tolerance in this case as the plant's ability to survive 10 to 14 days of complete submergence and continue their growth process after the flood recedes, with little damage to plant morphology. This problem is endemic in river basin areas, and it often leads to complete yield loss due to flash flood. Xu et al. [19] cloned the SUB1 gene from the FR13A 
landrace from India, which was adapted to submerge at the vegetative stage. The third category of flooding occurs in lowland rice cultivation, where the water level ranges from 20 to $50 \mathrm{~cm}$ depending on whether it is a rainfed or irrigated system. However, due to seasonal changes and rain duration, the water level might exceed $50 \mathrm{~cm}$, up to $4 \mathrm{~m}$, which lasts for a prolonged period of time and could partially or completely submerge the plant, depending on the growth stage. This type of flooding may remain for few months depending on the area. Many landraces, also known as floating rice, are adapted to this type of flooding and can extend up to $25 \mathrm{~cm}$ per day as the flood level increases [18].

Generally, stagnant flooding occurs as a result of heavy rain, which can be deep-water flooding or flash flooding. Under deep-water flooding, plants increase their stem length (internode) to escape the submergence. However, after the flood subsides, affected plants are prone to lodging and eventually this leads to death due to the exhaustion of reserved nutrients within few days. Contrarily, during flash flood, plant growth is restricted and resumes after occurrence of the flood [20]. Regardless of the temperature, duration, and depth of the flood, flood has a major impact and threatens plants with a shortage of carbohydrates and cellular energy, which hinders growth and development (Figure 2). Rainwater flooding is usually clear water, which results in less crop damage as compared to turbid or silted water. Hence, comprehensive knowledge of the relationship between plant survival and flood water qualities is a prerequisite for the development of flood tolerance and sustainable flood management practices.

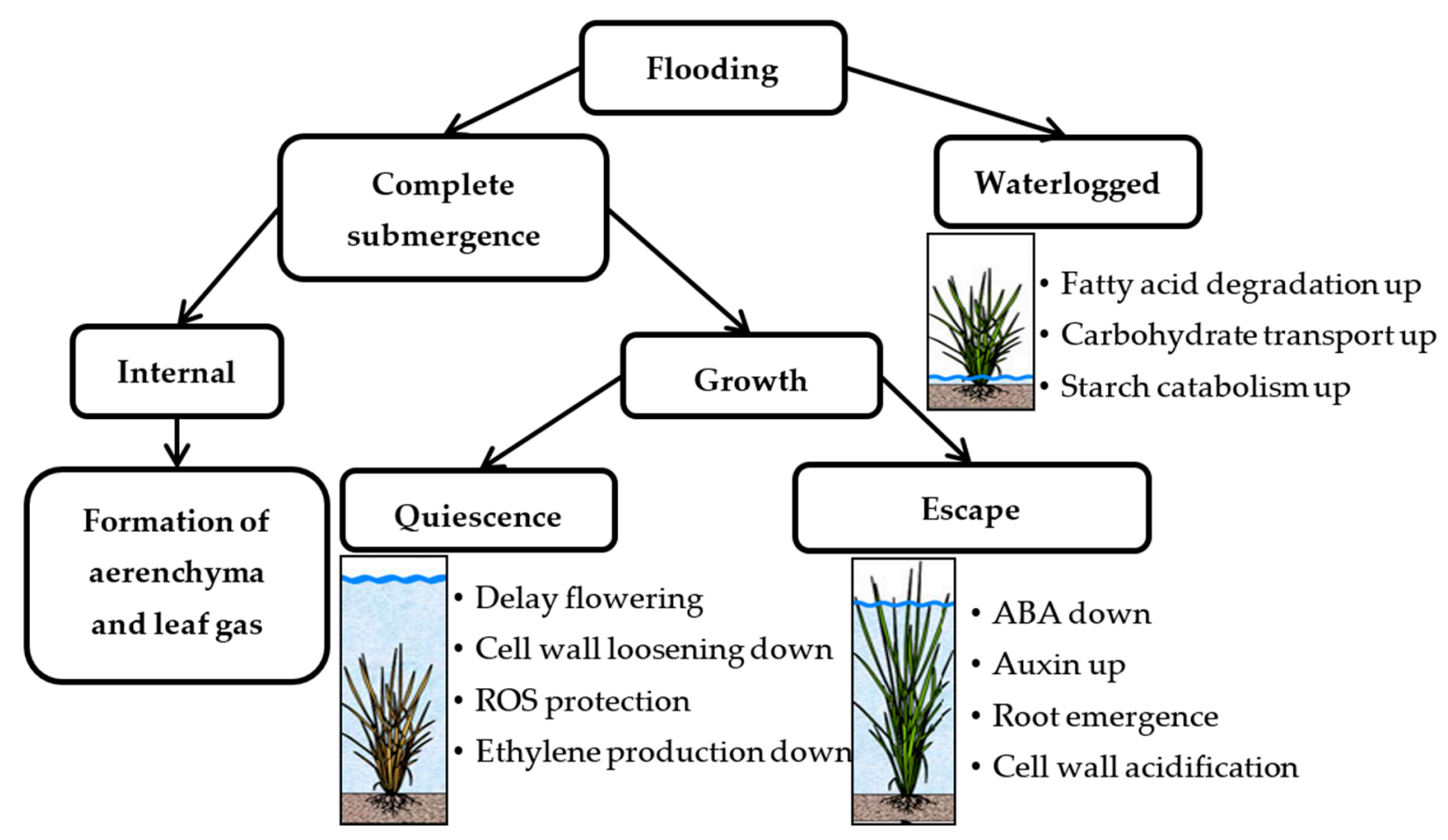

Figure 2. Rice strategies for adaptation to submergence and waterlogging.

To a greater extent, light intensity, turbidity, temperature, $\mathrm{pH}$, gas diffusion, aerenchyma, and leaf morphology are the most significant factors that influence plant growth and survival. During submergence, light intensity reaching the leaves is diminished by suspended phytoplankton or silt and dissolved organic matter in the water. Similarly, during flash floods, the water is mostly turbid and only a meagre amount of solar radiation can reach the plant canopy, thereby limiting the photosynthesis rate. Under submergence, light intensity is a major factor controlling the concentration of carbon dioxide and oxygen, which has a significant impact on the physiological status of the submerged plant [21]. Generally, plants produce oxygen through photosynthesis. However, a lack of effective oxygen transport system to non-photosynthesis organs infers that these organs dispossess oxygen if their physiological mechanism restricts the diffusion of oxygen to the outsides [22]. In addition, plants 
respond differently to insufficient oxygen, limiting respiration (hypoxia), and a complete absence of oxygen (anoxia), which is detrimental to plant survival [22]. Flooding conditions can drastically affect plant survival. As reported by Pucciariello et al. [23], large survival differences exist between completely submerged plants in darkness versus those submerged with some light, suggesting the importance of photosynthesis under water. Waterlogging hampers the development and function of roots and shoots due to a shortage of oxygen, which restricts respiration. The consequences of photosynthesis blockage and root aerobic respiration are a result of the light intensity of the water, $\mathrm{CO}_{2}$, and $\mathrm{O}_{2}$ [11].

Oxygen deficiency and low light intensity are the two major factors that limit the survival ability of rice plants under prolonged submergence; these are due to the failure of plant sensitivity to develop new leaves and the severe damage caused on the older leaves. Furthermore, the submerged plants are often deprived of oxygen and high light tension, which results in the formation of reactive oxygen species (ROS) such as hydrogen peroxide, hydroxyl radical, and superoxide anion that, if not moderated, can seriously damage cellular organization, which can lead to plant death. However, rice cultivars that are efficient in ROS detoxification after de-submergence are characterized by the ability to retain chlorophyll, sustain plant growth, regenerate new leaves, and maintain the older leaves. Hence, rice plants protect themselves against oxidative damage using two mechanisms: (i) the presence of antioxidant enzyme systems, (ii) natural antioxidants. Low-molecular-weight naturally occurring antioxidants compounds, such as phenols, a-tocopherol, ascorbate, carotenoids, and glutathione, are found to have reduced oxidative damage in plants. However, among these compounds, only ascorbate has been studied. Hancock and Viola [24] and Das et al. [25] reported higher levels of ascorbate in the root system under hypoxia, while it declined upon re-aeration. Therefore, ascorbate plays an important role in protecting plants against ROS damage.

Quiescence strategy is observed by traits that conserve carbohydrates and energy under prolonged flooding conditions and recover normal growth and development after the flood subsides, whereas escape strategy is recognized by the collection of anatomical and morphological traits that enable gaseous exchange between submerged and non-submerged organs through elongation. Kende et al. [26] studied physiological mechanisms, and suggested that gibberellin (GA), abscisic acid (ABA), and ethylene are the major plant hormones involved in deep-water rice elongation. Schaller and Bleecker [27] described ethylene as the only gaseous plant hormone, and it controls many plant characteristics, which include growth, development, and senescence. Ethylene has been extensively studied as the major factor regulating internode elongation among hormones responsible for deep-water elongation. Physiological studies have shown the relationship between deep-water elongation and ethylene response [26]. During complete submergence, there is a rapid increase in intralacunar ethylene content and the application of an ethylene inhibitor suppresses the elongation of the internode [28]. Similarly, low oxygen sensing stimulates internode elongation [29]. Upon re-oxygenation after a period of oxygen deprivation, ethanol that was trapped in the tissues is converted into acetaldehyde, which causes post anoxic cell damage. Also, reactive oxygen species (ROS) accumulate excessively upon re-oxygenation or oxygen deprivation under light conditions [11].

\section{Rice germ Plasm Tolerant to Different Flooding Regimes}

Landraces and traditional rice varieties are well adapted to abiotic factors such as flood, drought, salinity, acid soil, heat, and cold conditions. A complete flooding regime in rice field causes chlorophyll senescence, restricts plant respiration, and inhibits aerobic respiration. Despite the challenges of this flooding, rice plants have evolved tolerance by adjusting their physiological plasticity, resulting in morphological, anatomical, and metabolic acclimatization. Traditionally, farmers cultivate flood-adapted landraces that can withstand flooding or complete submergence for more than 10 days and resume normal growth after flood subsides to avoid flooding disasters [30]. A range of survival strategies to waterlogging and submergence are recognized among cultivated and wild species, which are characterized as quiescence and escape as both extremes [14]. The distinction in rice responses to 
submergence displayed by quiescence and escape mechanism illustrates subtle stability between the conservation versus utilization of reserves when the overall energy produced is compromised.

Plants' ability to reserve and maintain high non-structural carbohydrate in shoots before, during, and after submergence is an important phenotypic characteristic of tolerance variety. This could be achieved by maintaining underwater photosynthesis through the preservation of chlorophyll in the leaves and slower shoot growth rate under submergence [31]. The importance of leaf gas firm and underwater photosynthesis for oxygen supply in rice fields under complete submergence were recently studied using oxygen microelectrodes [20]. Photosynthetic activities under water contributed to submergence tolerance by improving both internal aeration and increasing carbohydrate reserves. This was supported by the findings of Ella et al. [32] that blocking ethylene, which induces chlorophyll degradation, can increase anoxia survival. In addition, continuous supply of carbohydrates during submergence is essential for survival. This was supported by the findings of Das et al. [33], that plants' survival is positively correlated with carbohydrates immediately after submergence as compared to carbohydrates during submergence. Other survival characteristics include the regulation of reactive oxygen species (ROS), leaf dehydration, recovery, and rapid regeneration after submergence [34].

The average yield potential of these landraces is $2 \mathrm{t} / \mathrm{ha}$ as compared to $6-8 \mathrm{t} / \mathrm{ha}$ of semi-draft commercial varieties. Unfortunately, the "semi-draft varieties", which are widely cultivated in Asia, are susceptible to flooding and die a few days after submergence. The submergence-tolerant varieties have resulted in a considerable increase in rice production and income to farmers in flood-prone areas [1]. Colmer et al. [35] extensively reviewed the molecular and physiological responses of rice to flooding and provided evidence for various characters linked with submergence tolerance. The most significant characteristic used in breeding is the dormancy of shoots induced by submergence. This rare characteristic was induced by a single mutation that occurs in Odisha, a flood-prone area in India, and later spread among landraces, predominantly in Sri Lanka and India [1]. This submergence mutation occurs in the ethylene response factor (ERFs) of transcription factor genes in the short arm of chromosome 9 on SUB1 locus. The SUB1 gene is up-regulated during submergence and down-regulated when the flood subsides, which ensures there is no effect after aeration [36]. Plants conferred with the SUB1 gene can tolerate up to 17 days dormancy of complete submergence during the vegetative stage.

Screening of germplasm for the identification of submergence-tolerant rice varieties at the International Rice Research Institute (IRRI) began in the 1970s [37]. Out of over 100,000 rice germplasms collected and maintained by the IRRI, less than 1000 submergence varieties were collected from core flood-prone areas. Bangladesh had the highest collection of 443, followed by Sri Lanka (82), India (42), Thailand (34), Cambodia (25), Vietnam (22), China (21), Indonesia (13), Myanmar (8), and 42 from other countries [38]. Systematic screening under controlled submergence conditions allowed IRRI researchers to evaluate thousands of genotypes. The screening for high submergence tolerance led to the discovery of two varieties, namely FR13A and FR43B. These varieties were collected from Odisha, formerly known as Orissa, located in eastern India. As reported by Vergara et al. [39], Indian scientists had previously identified these varieties as "flood-resistant", therefore the name FR was designated. These varieties were pure lines selected from traditional varieties. FR13A was selected from Dhalputtia, while FR43B was selected from Bhetnasia. Further screening at different environments and seasons later confirmed the strong tolerance of FR13A [40]. Based on the available literature, FR13A is the most recognized submergence tolerant landrace and has been widely used as a donor parent for tolerance in breeding programs. Similarly, it has been widely used for quantitative trait locus (QTL) association mapping and subsequent map-based cloning of the SUB1 gene.

Vergara and Mazaredo [37] identified some high submergence-tolerant rice varieties from Sri Lanka after seven days submergence of 10-day-old seedlings and measured the survival rate of recovery after five days. Highly tolerant varieties showed more than $75 \%$ survival rate. Some of these varieties, such as Thavalu, Kurkaruppan, and Goda Heenati, have been extensively used in crop improvement and studies of submergence tolerance. Through standardized methods of screening at the IRRI, landraces tolerant to flooding at the germination stage were identified, which include Ma-Zhan Red, 
Nanhi, Khao Hlan On, and Khaiyan [17]. These rice germplasms have been used in physiological studies and genetic mapping for the development of improved rice lines with high levels of tolerance to aerobic germination stress using molecular and conventional breeding methods [41]. In India, rice varieties such as Sabita, Ambika, Saraswati, and Hangseswari are recommended by the Indian Council of Agricultural Research for deep-water rice farmers. These varieties, such as Hangseswari, can produce up to $2.5 \mathrm{t} /$ ha grain yield under deep-waterlogged conditions (www.icar.org.in). Some varieties, such as Leuang Pratew 123 and Khao Tah Haeng 17, are capable of tolerating both stagnant floods of up to $80 \mathrm{~cm}$ and flash floods during the early vegetative growth stage. Although these varieties do not possess internode elongation properties, they are widely cultivated in low-lying areas. Some of the major advantages of these varieties contributing to flood tolerance include tolerance to drought, flexibility in planting time, tolerance to soil-related stressors, and plant height $150-180 \mathrm{~cm}$ to withstand $80 \mathrm{~cm}$ of water [42].

Previous studies on understanding the genetic mechanism of submergence tolerance in rice revealed that submergence is controlled by both simple and quantitative inheritance $[43,44]$. $\mathrm{Xu}$ and Mackill [45] mapped a major QTL designated as SUB1 on chromosome 9 associated with submergence tolerance, using a cross between a sensitive japonica line (PI543851) and an indica tolerant line (IR40931-26) that accounted for 70\% of the total phenotypic variance in this population. The IR40931-26 used for the QTL analysis was derived from FR13A, which is the most submergence-tolerant cultivar. Following the identification of the SUB1 gene on chromosome 9, numerous studies have confirmed the importance of SUB1 in submergence-tolerant cultivars, and additional but minor QTLs were also identified on other chromosomes [44,46].

\section{Molecular and QTL}

The recent advancement in molecular biology and marker technologies has paved the way for QTL analysis, fine mapping, and subsequent cloning of the submergence tolerance gene. The molecular basis for submergence tolerance has been well studied for traits linked with flood tolerance in rice. Among these traits, deep-water elongation was the first to capture the attention of plant breeders and geneticists due to its unique quality. Ramiah and Ramaswami [46] were the first to reveal that duplicated genes control internode elongation and was designated as ef1 and ef2 (elongation factor) using the conventional breeding method, while studying the inheritance pattern of stem elongation in deep-water rice. Subsequently, Hamamura and Kupkanchankul [47] reported a partial dominance and five to six genes responsible for the floating of deep-water rice using allele crosses and analyzing the progeny for submergence tolerance. However, according to Tripathi and Rao [48], a single dominant gene controls early nodal differentiation, whereas Suge [49] reported the action of complementary genes that control internode elongation in deep-water rice. Eiguchi et al. [50] concluded that single recessive gene $d w 3$ controlled internode elongation in deep-water rice.

The major landmark in the history of submergence tolerance breeding was the identification of QTL controlling the submergence, which was designated as the SUB1 gene [45]. Identification of the genomic segment encoding the SUB1 QTL had been narrowed down to a small chromosomal region. The gene was later cloned and identified to be an ethylene response factor (ERF) [19]. This genomic region was further mapped to a $0.16 \mathrm{cM}$ region on chromosome 9, with approximately 3000 F2 progeny [51]. Subsequently, using a fine-scale physical mapping study, Xu et al. [19] narrowed the locus down to $0.075 \mathrm{cM}$ using $4022 \mathrm{~F} 2$ individuals. Septiningsih et al. [52] identified four novel QTLs on chromosomes 1, 2, 9, and 12 in a cross between IR72 and Madabaru (both moderate submergence tolerant varieties) at F2:3 populations. A subset of 80 families was selected from the two extreme sides for the QTL analysis from the F2:3 population of 466 families using phenotypic screening under submergence stress. Also, three non-SUB1 QTLs from IR72 were identified, which suggests that alternative pathways may exist independent of the ethylene-dependent pathway of the SUB1 gene [52].

Sripongpangkul et al. [53] performed QTL analysis in a recombinant inbred lines (RILs) cross of IR74/Jalmagna using leaf length, internode length, and plant height increment to determine the stem 
elongation mechanism in deep-water rice, and detected 26 QTLs regulating submergence tolerance and plant elongation. Using the rate of internode elongation (RIE) and lowest elongated internode (LEI), Kawano et al. [54] detected two QTLs on chromosomes 1 and 12, and 3 and 12 for each trait, respectively. Similarly, Nemoto et al. [55] detected two QTLs on chromosomes 3 and 12 using the LEI trait. Using three parameters, REI, LEI, and total internode elongation length (TIL), on three different populations, Hattori et al. [56] identified three QTLs on 1, 3, and 12 in similar genomic regions in different populations. These, however, suggest that such QTLs are constantly responsible for elongation in response to flooding in deep-water rice. Furthermore, Hattori et al. [57] reported QTL on chromosome 12, which is most effective for internode elongation in deep-water using near-isogenic lines (NILs) on genetic background of Taichung65 (NIL-1, NIL-3, and NIL-12). In deep-water rice, elongation under water is considered the most important phenotyping trait in QTL analysis. Using this trait, Nagai et al. [51] identified two new QTLs, qTIL2 and qTIL4, controlling total internode elongation during the seedling stage. Research studies on the identification of QTLs controlling different types of submergence tolerance were summarized in Table 1. The mapping of major QTLs associated with anaerobic germination (AG) has been carried out and identified at the IRRI [17,57-59]. Among these QTLs, qAG-9-2 was mapped to circa $50 \mathrm{~kb}$ on chromosome 9 using the Khao Hlan On rice variety [17]. The gene encoding a trehalose-6-phosphate phosphatase (OsTPP) confers stress tolerance has been cloned and functionally validated [60]. This QTL has also been transferred to popular high-yielding rice varieties [41].

In order to establish a more effective marker-assisted selection (MAS) breeding scheme for introgression of flood tolerance traits from landraces to commercial varieties, it is essential to find additional DNA diagnostic markers that are tightly linked with the traits of interest, which will primarily come from a fine mapping of the identified QTLs. Isolation of these QTLs underlying genes will help in designing more accurate gene-specific DNA markers for MAS and would also advance our understanding of the physiological and genetic mechanisms of flood tolerance. Furthermore, such research would facilitate stronger and new alleles for tolerance. However, the application of MAS in quantitative traits improvement in plant breeding is hindered by the low predictive value of QTL markers for performance. This is caused by numerous factors, such as strong genotype by environment interaction [61], low expression of certain genes, and recombination between markers and target genes [62,63]. Genome sequencing projects have made it possible to use known candidate gene sequences as markers to associate with target traits. The candidate gene approach has emerged as a promising method of merging QTL analysis with the extensive data available on the cloning and characterization of genes involved in plant stressors [64]. 
Table 1. Summary of quantitative trait locus for submergence tolerance traits in rice.

\begin{tabular}{|c|c|c|c|c|}
\hline Cross & Trait & Population & Chromosome & Reference \\
\hline Nanhi $\times$ IR64 & $\begin{array}{l}\text { anaerobic } \\
\text { germination }\end{array}$ & $\mathrm{F}_{2}, \mathrm{~F}_{3}$ & $2,7,11$ & [52] \\
\hline $\begin{array}{l}\text { Bhaduaf } \times \\
\text { Taichung } 65\end{array}$ & $\begin{array}{l}\text { lowest elongated } \\
\text { internode, rate of } \\
\text { internode } \\
\text { elongation }\end{array}$ & $\mathrm{F}_{2}$ & $1,3,12$ & [47] \\
\hline FR13A × KDML105 & $\begin{array}{l}\text { vegetative stage } \\
\text { submergence }\end{array}$ & Backcross line & $1,7,9$ & [65] \\
\hline $\mathrm{IR} 42 \times \mathrm{FR} 13 \mathrm{~A}$ & Survival rate & $\begin{array}{l}\text { recombinant inbred } \\
\text { line }\end{array}$ & $1,4,8,9,10$ & [66] \\
\hline $\begin{array}{l}\text { USSR5 (japonica) x } \\
\text { N22 (indica) }\end{array}$ & $\begin{array}{l}\text { Germination under } \\
\text { low temperature } \\
\text { and anoxia }\end{array}$ & $\mathrm{F}_{2}$ & 5,11 & [67] \\
\hline $\begin{array}{c}\text { 1R40931-26 } \times \\
\text { PI543851 }\end{array}$ & $\begin{array}{l}\text { vegetative stage } \\
\text { submergence }\end{array}$ & $\mathrm{F}_{2}$ & 9 & [45] \\
\hline Jalmagna $\times$ IR74 & $\begin{array}{l}\text { vegetative stage } \\
\text { submergence }\end{array}$ & $\begin{array}{l}\text { recombinant inbred } \\
\text { line }\end{array}$ & 9 & [46] \\
\hline $\begin{array}{c}\text { Habiganj Aman } \times \\
\text { Patnai23 }\end{array}$ & $\begin{array}{l}\text { lowest elongated } \\
\text { internode }\end{array}$ & $\mathrm{F}_{2}$ & 1,12 & [68] \\
\hline $\begin{array}{l}\text { 1R49830-7-1-2 } \times \\
\text { CT6241-17-1-5-1 }\end{array}$ & $\begin{array}{l}\text { vegetative stage } \\
\text { submergence }\end{array}$ & $\begin{array}{l}\text { Doubled Haploid } \\
\text { Line, recombinant } \\
\text { inbred line, } \mathrm{F}_{2}\end{array}$ & 9 & [44] \\
\hline T $65 \times$ Bhadua & $\begin{array}{l}\text { total internode } \\
\text { length }\end{array}$ & $\begin{array}{l}\text { recombinant inbred } \\
\text { line }\end{array}$ & 2,4 & [51] \\
\hline TX9425 x Naso Nijo & $\begin{array}{l}\text { Membrane } \\
\text { potential and } \\
\text { hypoxia }\end{array}$ & $\begin{array}{l}\text { Doubled Haploid } \\
\text { Line }\end{array}$ & 2 & [69] \\
\hline Madabaru $\times$ IR72 & $\begin{array}{l}\text { vegetative stage } \\
\text { submergence }\end{array}$ & $\mathrm{F}_{2}, \mathrm{~F}_{3}$ & $1,2,9,12$ & [52] \\
\hline Goai $\times$ Patnai 23 & $\begin{array}{l}\text { lowest elongated } \\
\text { internode }\end{array}$ & $\mathrm{F}_{2}$ & 3,12 & [48] \\
\hline $\begin{array}{c}\text { Ma-Zhan }(\text { Red }) \times \\
\text { IR42 }\end{array}$ & $\begin{array}{c}\text { anaerobic } \\
\text { germination }\end{array}$ & Backcross line & $2,5,6,7$ & [70] \\
\hline FR13A $\times$ IR74 & $\begin{array}{l}\text { vegetative stage } \\
\text { submergence }\end{array}$ & $\begin{array}{l}\text { recombinant inbred } \\
\text { line }\end{array}$ & $6,7,9,11,12$ & [71] \\
\hline $\begin{array}{l}\text { Khao Hlan On } \times \\
\text { IR64 }\end{array}$ & $\begin{array}{l}\text { anaerobic } \\
\text { germination }\end{array}$ & Backcross line & $1,3,7,9$ & [17] \\
\hline Nipponbare $\times$ IR64 & $\begin{array}{l}\text { coleoptile } \\
\text { elongation }\end{array}$ & $\begin{array}{l}\text { recombinant inbred } \\
\text { line }\end{array}$ & 1 & [72] \\
\hline Nipponbare/Kasalath/ & $\begin{array}{l}\text { Submergence } \\
\text { /Nipponbarke } \\
\text { tolerance }\end{array}$ & Backcross line & $1,3,4,6,7$ & [73] \\
\hline DX18-121 X M-202 & $\begin{array}{c}\text { Submergence } \\
\text { tolerance }\end{array}$ & $\mathrm{F}_{2}$ & 9 & [51] \\
\hline $\mathrm{C} 9285 \times \mathrm{T} 65$ & $\begin{array}{l}\text { lowest elongated } \\
\text { internode, total } \\
\text { internode length, } \\
\text { number of } \\
\text { elongated } \\
\text { internode }\end{array}$ & Backcross line & $1,3,12$ & [49] \\
\hline
\end{tabular}

\section{SUB1's Gene: From Landrace to Modern Cultivar}

It is important to cross landraces as a donor parent with elite cultivars to obtain varieties with tolerance to submergence as a means of overcoming agronomic limitations, such as photoperiod sensitivity, reduced yield, and sub-optimal yields of poor-quality grain, and susceptibility to insects, pests, and diseases. Since the 1980s, attempts have been made to create such a variety $[43,74]$. However, the 1990s witnessed the production of the IR49830-7-1-2-2 of the FR13A-derived breeding line and the 
gene carrying the tolerance to submergence was introduced to high-yielding short-to-intermediate statured lines $[75,76]$. The field trials and greenhouse evaluation of these breeding populations were reported to have prolonged tolerance under submerged condition after 50 days of planting. Submergence tolerance was shown to be controlled by a single gene, with some minor genes having less significant effects. Submergence tolerance for genetic studies and breeding was sourced from local landraces, which included Kurkaruppan, Thavalu, Goda Heenati, FR13A, and FR13B [37,40]. These varieties were selected for crossing at the International Rice Research Institute and the result was the development of some semi-dwarf submergence-tolerant varieties. However, limitations, such as poor grain quality and sub-optimal yield, inherited from the parent landraces prevented the adoption of the developed varieties [77].

The most remarkable advancement in breeding with regards to flooded condition was the discovery of the submergence 1 (SUB1) gene, which confers tolerance to complete submergence [1]. The discovery of the SUB1 QTL allows its incorporation through marker-assisted backcrossing (MABC) into varieties which are widely adopted by farmers [77,78]. Marker-assisted backcrossing is used in introgressing the genomic region carrying the SUB1A into high-yielding varieties, such as BR11, CR1009, Thadokkam 1 (TDK1), IR64, Samba Mahsuri, and Swarna [79]. Microsatellite markers that were polymorphic between the two parents were used to enhance the combination of the recurrent parent genome with the SUB1 region located on chromosome 9 of the FR13A. Several screenhouse and field evaluations of submergence tolerance established that all "SUB1" lines demonstrated a considerably higher tolerance to complete submergence, unlike their parents $[34,79,80]$. An extensive marker-assisted backcrossing (MABC) program was initiated by the International Rice Research Institute in order to initiate the SUB1 gene into the prominent varieties ("mega-varieties") with many prominent features, such as high yield and superior grain quality, but lacking the ability to tolerate submergence. The SUB1 gene was observed to confer tolerance to complete submergence in about 10-18 days. Exploiting the precision of the marker-assisted backcrossing enabled the retention of desirable qualities (yield, grain quality, and agronomic traits) of the mega-varieties $[79,81]$.

To ascertain a high level of precision and reduce the time required for variety development in breeding programs, three tiers of MABC, namely foreground, recombinant, and background selection, are employed [82]. Foreground selection involves the use of markers which are closely-linked to SUB1 in selecting for this gene. Recombinant selection entails the use of closely-associated flanking markers to reduce the donor chromosomal segment carrying the SUB1, while background selection describes the use of DNA markers to hasten the recovery of the recurrent parent genome. Specifically, recombinant selection is used as a means of minimizing the extent of the donor chromosome segment. This is important to retain the inherent qualities of the mega-varieties [83]. This method of selecting recombinants on both sides of the target locus in at least two backcross generations during marker-assisted backcrossing was first proposed decades ago [84]. As of 2012, marker-assisted backcrossing has been used to develop eight varieties by incorporating the SUB1 gene into them, while several others are still in the process of improvement. The recent field trials of the SUB1 varieties on farmers' fields have shown that there is no negative expression of SUB1 on other traits $[34,80]$, and in a short period of time, these improved mega-varieties have become popular with the farmers [77].

These studies have proven that the process of introgressing the SUB1 region of FR13A through marker-assisted backcrossing can be extensively applied to varying genetic backgrounds. Aside from submergence tolerance, the influence of SUB1 on grain production, quality, and maturation were tested in Samba Mahsuri-Sub1, Swarna-Sub1, and IR64-Sub1. An experiment to compare the three Sub1 varieties and their original parents showed that incorporation of the SUB1 gene had no adverse effect on agronomical performance, such as yield and grain quality, where regular growth conditions are maintained [21,34]. Complete submergence at the vegetative stage of non-tolerant varieties significantly decreased the number of panicles, number of grains per panicle, grain-filling percentage, and delays flowering and maturity, causing a dramatic decline in grain yield. Sub1 rice curtails the reduction of 
these reproductive qualities in a submergence event, producing three- to six-fold more grain weight relative to the non-Sub1 varieties [34].

The main advantage of using the marker-assisted backcrossing approach is that the ensuing SUB1 varieties maintain all the desirable traits of the recurrent parent, particularly its quality and yield attribute characteristics. One of the reasons which prevented the wide acceptance of the earlier SUB1 varieties, such as IR49830-7-1-2-2, was due to the persistence of the genomic regions from the non-recurrent parent [77]. Varieties with a SUB1 region from FR13A have similar yield and other agronomic qualities to the original varieties when cultivated under shallow paddy conditions in the field. When subjected to total submergence for 7-15 days, considerable yield advantages were noticed in the varieties $[34,80]$. The distribution and acceptance of the Sub1 mega-varieties were relatively easier because the primary objective was to replace the original mega variety with an improved submergence-tolerant version. The SUB1 mega-varieties have also been reported to perform optimally under non-flood condition. Significantly, these introgression lines can serve as replacement for some low-yielding conventional landraces cultivated in submergence-prone regions, thus increasing yields in marginalized fields.

Results of the field trial of the new lines prompted many national rice improvement schemes in Asia to begin rapid seed multiplication and dissemination of the developed lines. From 2009 to 2010, Swarna-Sub1 was introduced in Bangladesh, India, and Indonesia, and BR11-Sub1 was made available in Bangladesh, while IR64-Sub1 was released in Indonesia and the Philippines [6]. The IRRI, as well as the national breeding programs in several countries in Asia, are introgressing several other varieties with SUB1.

\section{Challenges and Future Prospects}

The introgression of the SUB1 region through marker-assisted breeding has significantly enhanced submergence tolerance in several mega-varieties without limiting their development, yield, or grain quality $[34,80]$. These new lines are capable of enduring submergence for the duration of the flooding after the seedling stage but before flowering, and the flood completely subsides within 10 to 20 days, depending on floodwater conditions [85], although in some SUB1 varieties, vegetative growth did not occur until the water level declined to $10-15 \mathrm{~cm}$. This was primarily due to the short stature of these varieties. Recent studies have shown that this phenomenon was not observed when SUB1 was incorporated into taller varieties or those with the ability to tolerate partial stagnant flooding $(20-50 \mathrm{~cm})$. The yield improvement occurring due to the SUB1 introgression in the lines was believed to greatly stabilize their yield in rainfed lowland environments characterized by flash flooding. Contrastingly, deep-water rice, unlike the SUB1 rice, escapes stagnant partial flooding by enhancing the growth of internodes [86]. Due to the difference through which deep-water rice genes SK1/SK2 and the submergence tolerance gene SUB1A regulate ethylene-mediated GA responsiveness, it is unlikely that these genes can be combined to develop genotypes that are tolerant to both stagnant and submergence flooding. Advances in knowledge of the regulatory networks vital for balancing energy management and growth under submerged conditions can assist in identifying natural genetic diversity in some loci, which could be exploited to enhance the adaptability of rice to submergence.

The reassessment of QTLs from FR13A and other varieties lacking SUB1A-1 but moderately tolerant to flooding can be useful in further improving submergence tolerance. There is a need to increase the yield of rice in marginal growing regions. This, among other things, can be achieved by generating rice genotypes which combine submergence tolerance with tolerance to other environmental stress conditions and characteristic grain quality that is preferred in the local market. Research has shown that early germinating rice varieties with early coleoptile elongation in anaerobic soil have been recognized and used in breeding programs at IRRI $[16,17]$ for direct seeding. The expression of the mentioned traits in specific developmental windows can enable its incorporation alongside SUB1. In coastal areas prone to flooding as a result of tidal waves, it would be beneficial to have rice that can tolerate saline floodwater. Also, in non-irrigated lowland regions where rainfall is the only source of 
water, growers will benefit from rice which is capable of tolerating drought. The success in combining submergence tolerance with other qualities may promote the recognition of other landraces, for which traits will be unearthed at molecular level before getting to the grower's field as improved varieties. It is believed that with the advancement in plant breeding and innovations in rice germplasm collection, these challenges will be overcome in due time to meet the increasing global demand for food.

\section{Conclusions}

The mechanism for rice survival under submerged conditions consists of internal aeration and growth controls (i.e., a quiescence strategy or an escape strategy). A landmark innovation in the identification of the SUB1 gene has helped to rapidly develop new rice varieties capable of tolerating flooding. Despite the aforementioned success, several aspects need to be covered in order to gainfully exploit the potentials of flood-prone environments for successful rice cultivation. The MABC technology stated in this article is a conservative approach which can yield optimal results in submergence tolerance in a timely manner. However, using this method, some essential limitations that are characteristic of a flood-prone environment have been left unattended. The SUB1 varieties are at risk of disease incidence and other abiotic limitations; these limitations must be improved upon thorough breeding efforts. Marker-assisted backcrossing can be an efficient method of handling single-gene traits, however, when handling more complicated traits, MABC may be ineffective, hence other measures need to be pursued. The gene banks of India and IRRI contain a diverse amount of rice landraces which had earlier been cultivated in flooded and deep-water rice-growing regions. It is possible to find superior alleles of the SUB1A gene or some newer genes, which may offer better protection under submerged condition. Additionally, it is important to find more genes that offer tolerance to aerobic germination and stagnant flooding in order to improve yield stability in the flood-prone areas. Such attempts can aid in the development of superior high-yielding varieties of rice for a rainfed agro-ecosystem in order to protect against loss which occurs during persistent flooding of rice fields in the monsoon season. Advances in breeding techniques are vital for subsequent improvement in submergence tolerance and in combining traits, particularly disease resistance and salinity and drought tolerance.

Author Contributions: Y.O., M.Y.R., and F.A. drafted the manuscript, while the proofreading, editing, and finishing were carried out by S.C.C., I.M., I.K., I.W.A. and M.A.S. All authors offered suggestions on various drafts of the manuscript. All authors have read and agreed to the published version of the manuscript.

Funding: The authors are grateful to the Ministry of Education Malaysia, for adequate research funding through the Higher Institutions Centre of Excellence ( $\mathrm{HICoE})$ to conduct research on improvement of rice varieties for adaption to biotic and abiotic stress.

Conflicts of Interest: The authors declare no conflict of interest.

\section{References}

1. Ismail, A.M.; Singh, U.S.; Singh, S.; Dar, M.H.; Mackill, D.J. The contribution of submergence-tolerant (Sub1) rice varieties to food security in flood-prone rainfed lowland areas in Asia. Field Crops Res. 2013, 152, 83-93. [CrossRef]

2. Bailey-Serres, J.; Lee, S.C.; Brinton, E. Waterproofing crops: Effective flooding survival strategies. Plant Physiol. 2012, 160, 1698-1709. [CrossRef] [PubMed]

3. Ahmed, Z. Disaster risks and disaster management policies and practices in Pakistan: A critical analysis of Disaster Management Act 2010 of Pakistan. Int. J. Dis. Risk Reduct. 2013, 4, 15-20. [CrossRef]

4. Olesen, J.E.; Trnka, M.; Kersebaum, K.C.; Skjelvåg, A.O.; Seguin, B.; Peltonen-Sainio, P.; Rossi, F.; Kozyra, J.; Micale, F. Impacts and adaptation of European crop production systems to climate change. Eur. J. Agron. 2011, 34, 96-112. [CrossRef]

5. Agri-Business Promotion and Statistics Division. Statistical Information on Nepalese Agriculture 2012/2013; Agriculture Business Promotion and Statistics DivisionMoADC, HMG/N, Singh Durbar: Kathmandu, Nepal, 2012. 
6. Bailey-Serres, J.; Fukao, T.; Ronald, P.C.; Ismail, A.M.; Heuer, S.; Mackill, D. Submergence tolerant rice: SUB1's journey from landrace to modern cultivar. Rice 2010, 3, 138-147. [CrossRef]

7. Wassmann, R.; Jagadish, S.V.K.; Sumfleth, K.; Pathak, H.; Howell, G.; Ismail, A.; Serraj, R.; Redona, E.; Singh, R.K.; Heuer, S.; et al. Regional vulnerability of climate change impacts on Asian rice production and scope for adaptation. Adv. Agron. 2009, 102, 91-133.

8. Sarkar, R.K.; Das, K.K.; Panda, D.; Reddy, J.N.; Patnaik, S.S.C.; Patra, B.C.; Singh, D.P. Submergence Tolerance in Rice: Biophysical Constraints, Physiological Basis and Identification of Donors; Central Rice Research Institute: Cuttck, India, 2014; pp. 1-36.

9. Godfray, H.C.J.; Beddington, J.R.; Crute, I.R.; Haddad, L.; Lawrence, D.; Muir, J.F.; Toulmin, C. Food security: The challenge of feeding 9 billion people. Science 2010, 327, 812-818. [CrossRef]

10. Colmer, T.; Voesenek, L.A.C.J. Flooding tolerance: Suites of plant traits in variable environments. Funct. Plant Biol. 2009, 36, 665-681. [CrossRef]

11. Voesenek, L.A.; Bailey-Serres, J. Flooding tolerance: $\mathrm{O}_{2}$ sensing and survival strategies. Curr. Opin. Plant Biol. 2013, 16, 647-653. [CrossRef]

12. Herzog, M.; Striker, G.G.; Colmer, T.D.; Pedersen, O. Mechanisms of waterlogging tolerance in wheat-A review of root and shoot physiology. Plant Cell Environ. 2016, 39, 1068-1086. [CrossRef]

13. Chukwu, S.C.; Rafii, M.Y.; Ramlee, S.I.; Ismail, S.I.; Oladosu, Y.; Okporie, E.; Jalloh, M. Marker-assisted selection and gene pyramiding for resistance to bacterial leaf blight disease of rice (Oryza sativa L.). Biotechnol. Biotechnol. Equip. 2019, 33, 440-455. [CrossRef]

14. Bailey-Serres, J.; Voesenek, L.A.C.J. Flooding stress: Acclimations and genetic diversity. Annu. Rev. Plant Biol. 2008, 59, 313-339. [CrossRef] [PubMed]

15. Dar, M.H.; Chakravorty, R.; Waza, S.A.; Sharma, M.; Zaidi, N.W.; Singh, A.N.; Ismail, A.M. Transforming rice cultivation in flood prone coastal Odisha to ensure food and economic security. Food Secur. 2017, 9, 711-722. [CrossRef]

16. Ismail, A.M.; Ella, E.S.; Vergara, G.V.; Mackill, D.J. Mechanisms associated with tolerance to flooding during germination and early seedling growth in rice (Oryza sativa). Ann. Bot. 2008, 103, 197-209. [CrossRef] [PubMed]

17. Angaji, S.A.; Septiningsih, E.M.; Mackill, D.J.; Ismail, A.M. Identification of QTLs associated with tolerance of anaerobic conditions during germination in rice (Oryza sativa L.). Euphytica 2010, 172, 159-168. [CrossRef]

18. Singh, A.; Septiningsih, E.M.; Balyan, H.S.; Singh, N.K.; Rai, V. Genetics, physiological mechanisms and breeding of flood-tolerant rice (Oryza sativa L.). Plant Cell Physiol. 2017, 58, 185-197.

19. Xu, K.; Xu, X.; Fukao, T.; Canlas, P.; Maghirang-Rodriguez, R.; Heuer, S.; Mackill, D.J. Sub1A is an ethylene-response-factor-like gene that confers submergence tolerance to rice. Nature 2006, 442, 705. [CrossRef]

20. Winkel, A.; Colmer, T.D.; Ismail, A.M.; Pedersen, O. Internal aeration of paddy field rice (Oryza sativa) during complete submergence-importance of light and floodwater $\mathrm{O}_{2}$. New Phytol. 2013, 197, 1193-1203. [CrossRef]

21. Sarkar, R.K.; Reddy, J.N.; Sharma, S.G.; Ismail, A.M. Physiological basis of submergence tolerance in rice and implications for crop improvement. Curr. Sci. 2006, 91, 899-906.

22. Loreti, E.; van Veen, H.; Perata, P. Plant responses to flooding stress. Curr. Opin. Plant Biol. 2016, 33, 64-71. [CrossRef]

23. Pucciariello, C.; Voesenek, L.A.; Perata, P.; Sasidharan, R. Plant responses to flooding. Front. Plant Sci. 2014, 5, 226. [CrossRef] [PubMed]

24. Hancock, R.D.; Viola, R. Biosynthesis and catabolism of L-ascorbic acid in plants. Crit. Rev. Plant Sci. 2005, 24, 167-188. [CrossRef]

25. Das, K.K.; Panda, D.; Nagaraju, M.; Sharma, S.G.; Sarkar, R.K. Antioxidant enzymes and aldehyde releasing capacity of rice cultivars (Oryza sativa L.) as determinants of anaerobic seedling establishment capacity. Bulg. J. Plant Physiol. 2004, 30, 34-44.

26. Kende, H.; van der Knaap, E.; Cho, H.T. Deep-water rice: A model plant to study stem elongation. Plant Physiol. 1998, 118, 1105-1110. [CrossRef]

27. Schaller, G.E.; Bleecker, A.B. Ethylene-binding sites generated in yeast expressing the Arabidopsis ETR1 gene. Science 1995, 270, 1809-1811. [CrossRef]

28. Métraux, J.P.; Kende, H. The role of ethylene in the growth response of submerged deep-water rice. Plant Physiol. 1983, 72, 441-446. [CrossRef] 
29. Raskin, I.; Kende, H. Role of gibberellin in the growth response of submerged deep-water rice. Plant Physiol. 1984, 76, 947-950. [CrossRef]

30. Ahmed, F.; Rafii, M.Y.; Ismail, M.R.; Juraimi, A.S.; Rahim, H.A.; Asfaliza, R.; Latif, M.A. Waterlogging tolerance of crops: Breeding, mechanism of tolerance, molecular approaches, and future prospects. BioMed Res. Int. 2012, 2013, 963525. [CrossRef]

31. Mommer, L.; Visser, E.J.W. Underwater photosynthesis in flooded terrestrial plants: A matter of leaf plasticity. Ann. Bot. 2005, 96, 581-589. [CrossRef]

32. Ella, E.; Kawano, N.; Yamauchi, Y.; Tanaka, K.; Ismail, A.M. Blocking ethylene perception enhances flooding tolerance in rice seedlings. Funct. Plant Biol. 2003, 30, 813-819. [CrossRef]

33. Das, K.K.; Sarkar, R.K.; Ismail, A.M. Elongation ability and non-structural carbohydrate levels in relation to submergence tolerance in rice. Plant Sci. 2005, 168, 131-136. [CrossRef]

34. Singh, S.; Mackill, D.J.; Ismail, A.M. Responses of Sub1 rice introgression lines to submergence in the field: Yield and grain quality. Field Crops Res. 2009, 113, 12-23. [CrossRef]

35. Colmer, T.D.; Armstrong, W.; Greenway, H.; Ismail, A.M.; Kirk, G.J.D.; Atwell, B.J. Physiological mechanisms in flooding tolerance of rice: Transient complete submergence and prolonged standing water. Prog. Bot. 2014, 75, 255-307.

36. Ismail, A.M. Submergence tolerance in rice: Resolving a pervasive quandary. New Phytol. 2018, 218, 1298-1300. [CrossRef] [PubMed]

37. Vergara, B.S.; Mazaredo, A. Screening for Resistance to Submergence under Greenhouse Conditions; Bangladesh International Rice Research Institute: Dhaka, Bangladesh, 1975; pp. 67-70.

38. Dwivedi, J.L. Screening Techniques and Genetics of Elongation Ability and Submergence Tolerance in Deep-Water Rice; International Rice Research Institute: Los Banos, Philippines, 1992.

39. Vergara, B.S.; Jackson, B.; De Datta, S.K. Deep Water Rice and its Response to Deep Water Stress. Climate and Rice; International Rice Research Institute: Los Banos, Philippines, 1976; pp. 301-319.

40. HilleRisLambers, D.; Vergara, B.S. Summary Results of an International Collaboration on Screening Methods for Flood Tolerance; International Rice Research Institute: Los Baños, Philippines, 1982; pp. 347-353.

41. Toledo, A.M.U.; Ignacio, J.C.I.; Casal, C.; Gonzaga, Z.J.; Mendioro, M.S.; Septiningsih, E.M. Development of improved Ciherang-Sub1 having tolerance to anaerobic germination conditions. Plant Breed. Biotechnol. 2015, 3, 77-87. [CrossRef]

42. Puckridge, D.W.; Kupkanchanul, T.; Palaklang, W.; Kupkanchanakul, K. Production of rice and associated crops in deeply flooded areas of the Chao Phraya delta. In Proceedings of the International Conference: The Chao Phraya Delta: Historical Development, Dynamics and Challenges of Thailand's Rice Bowl, Bangkok, Thailand, 12-15 December 2000; pp. 12-15.

43. Haque, Q.A.; Lambers, D.H.R.; Tepora, N.M.; Dela Cruz, Q.D. Inheritacne of submergence tolerance in rice. Euphytica 1989, 41, 247-251. [CrossRef]

44. Toojinda, T.; Siangliw, M.; Tragoonrung, S.; Vanavichit, A. Molecular genetics of submergence tolerance in rice: QTL analysis of key traits. Ann. Bot. 2003, 91, 243-253. [CrossRef]

45. Xu, K.; Mackill, D.J. A major locus for submergence tolerance mapped on rice chromosome 9. Mol. Breed. 1996, 2, 219-224. [CrossRef]

46. Ramiah, K.; Ramaswami, K. Floating habit in rice. Indian J. Agric. Sci. 1940, 11, 1-8.

47. Hamamura, K.; Kupkanchankul, T. Inheritance of floating ability of rice. Jpn. J. Breed. 1979, 29, $211-216$. [CrossRef]

48. Tripathi, R.S.; Rao, M.J.B. Inheritance studies of characters associated with floating habit and their linkage relationship in rice. Euphytica 1985, 34, 875-881. [CrossRef]

49. Suge, H. Physiological genetics of internode elongation under submergence in floating rice. Jpn. J. Genet. 1987, 62, 69-80. [CrossRef]

50. Eiguchi, M.; Hirano, H.Y.; Sano, Y.; Morishima, H. Effect of water depth on internode elongation and floral induction in a deep-water-tolerant rice line carrying the dw3 gene. Jpn. J. Breed. 1993, 43, 135-139. [CrossRef]

51. Xu, K.; Xu, X.; Ronald, P.C.; Mackill, D.J. A high-resolution linkage map of the vicinity of the rice submergence tolerance locus Sub1. Mol. Gen. Genet. 2000, 263, 681-689. [CrossRef] [PubMed]

52. Septiningsih, E.M.; Sanchez, D.L.; Singh, N.; Sendon, P.M.; Pamplona, A.M.; Heuer, S. Identifying novel QTLs for submergence tolerance in rice cultivars IR72 and Madabaru. Theor. Appl. Genet. 2012, 124, 867-874. [CrossRef] [PubMed] 
53. Sripongpangkul, K.; Posa, G.B.T.; Senadhira, D.W.; Brar, D.; Huang, N.; Khush, G.S. Genes/QTL affecting flood tolerance in rice. Theor. Appl. Genet. 2000, 101, 1074-1081. [CrossRef]

54. Kawano, R.; Doi, K.; Yasui, H.; Mochizuki, T.; Yoshimura, A. Mapping of QTL for floating ability in rice. Breed. Sci. 2008, 58, 47-53. [CrossRef]

55. Nemoto, K.; Ukai, Y.; Tang, D.Q.; Kasai, Y.; Morita, M. Inheritance of early elongation ability in floating rice revealed by diallel and QTL analyses. Theor. Appl. Genet. 2004, 109, 42-47. [CrossRef]

56. Hattori, Y.; Miura, K.; Asano, K.; Yamamoto, E.; Mori, H.; Kitano, H. A major QTL confers rapid internode elongation in response to water rise in deep-water rice. Breed. Sci. 2007, 57, 305-314. [CrossRef]

57. Hattori, Y.; Nagai, K.; Mori, H.; Kitano, H.; Matsuoka, M.; Ashikari, M. Mapping of three QTLs that regulate internode elongation in deep-water rice. Breed. Sci. 2008, 58, 39-46. [CrossRef]

58. Nagai, K.; Kuroha, T.; Ayano, M.; Kurokawa, Y.; Angeles-Shim, R.B.; Shim, J.H. Two novel QTLs regulate internode elongation in deep-water rice during the early vegetative stage. Breed. Sci. 2012, 62, 178-185. [CrossRef] [PubMed]

59. Baltazar, M.D.; Ignacio, J.C.; Thomson, M.J.; Ismail, A.M.; Mendioro, M.S.; Septiningsih, E.M. QTL mapping for tolerance of anaerobic germination from IR64 and the aus landrace Nanhi using SNP genotyping. Euphytica 2014, 97, 251-260. [CrossRef]

60. Kretzschmar, T.; Pelayo, M.A.F.; Trijatmiko, K.R.; Gabunada, L.F.; Alam, R.; Jimenez, R. A trehalose-6-phosphate phosphatase enhances anaerobic germination tolerance in rice. Nat. Plants 2015, 1, 15124. [CrossRef] [PubMed]

61. Oladosu, Y.; Rafii, M.Y.; Abdullah, N.; Magaji, U.; Miah, G.; Hussin, G.; Ramli, A. Genotype× Environment interaction and stability analyses of yield and yield components of established and mutant rice genotypes tested in multiple locations in Malaysia. Acta Agric. Scand. Sect. B Soil Plant Sci. 2017, 67, 590-606. [CrossRef]

62. Paterson, A.H.; Damon, S.; Hewitt, J.D.; Zamir, D.; Rabinowitch, H.D.; Lincoln, S.E.; Lander, E.S.; Tanksley, S.D. Mendelian factors underlyiing quantitative traits in tomato: Comparison across species, generation and environments. Genetics 1991, 127, 181-197.

63. Young, N.D. QTL mapping and quantitative disease resistance in plants. Annu. Rev. Phytopathol. 1996, 34, 479-501. [CrossRef]

64. Faris, J.D.; Li, W.L.; Liu, D.J.; Chen, P.D.; Gill, B.S. Candidate gene analysis of quantitative disease resistance in wheat. Theor. Appl. Genet. 1999, 98, 219-225. [CrossRef]

65. Siangliw, M.; Toojinda, T.; Tragoonrung, S.; Vanavichit, A. Thai jasmine rice carrying QTLch9 (SubQTL) is submergence tolerant. Ann. Bot. 2003, 91, 255-261. [CrossRef]

66. Gonzaga, Z.J.C.; Carandang, J.; Sanchez, D.L.; Mackill, D.J.; Septiningsih, E.M. Mapping additional QTLs from FR13A to increase submergence tolerance beyond SUB1. Euphytica 2016, 209, 627-636. [CrossRef]

67. Jiang, L.; Liu, S.; Hou, M.; Tang, J.; Chen, L.; Zhai, H.; Wan, J. Analysis of QTLs for seed low temperature germinability and anoxia germinability in rice (Oryza sativa L.). Field Crops Res. 2006, 98, 68-75. [CrossRef]

68. Tang, D.Q.; Kasai, Y.; Miyamoto, N.; Ukai, Y.; Nemoto, K. Comparison of QTLs for early elongation ability between two floating rice cultivars with a different phylogenetic origin. Breed. Sci. 2005, 55, 1-5. [CrossRef]

69. Gill, M.B.; Zeng, F.; Shabala, L.; Zhang, G.; Fan, Y.; Shabala, S.; Zhou, M. Cell-based phenotyping reveals QTL for membrane potential maintenance associated with hypoxia and salinity stress tolerance in barley. Front. Plant Sci. 2017, 8, 1941. [CrossRef] [PubMed]

70. Septiningsih, E.M.; Ignacio, J.C.; Sendon, P.M.; Sanchez, D.L.; Ismail, A.M.; Mackill, D.J. QTL mapping and confirmation for tolerance of anaerobic conditions during germination derived from the rice landrace Ma-Zhan Red. Theor. Appl. Genet. 2013, 126, 1357-1366. [CrossRef] [PubMed]

71. Nandi, S.; Subudhi, P.K.; Senadhira, D.; Manigbas, N.L.; Sen-Mandi, S.; Huang, N. Mapping QTLs for submergence tolerance in rice by AFLP analysis and selective genotyping. Mol. Gen. Genet. 1997, 255, 1-8. [CrossRef] [PubMed]

72. Hsu, S.K.; Tung, C.W. Genetic mapping of anaerobic germination-associated QTLs controlling coleoptile elongation in rice. Rice 2015, 8, 38. [CrossRef]

73. Manangkil, O.E.; Vu, H.T.T.; Mori, N.; Yoshida, S.; Nakamura, C. Mapping of quantitative trait loci controlling seedling vigor in rice (Oryza sativa L.) under submergence. Euphytica 2013, 192, 63-75. [CrossRef]

74. Mohanty, H.K.; Chaudhary, R.C. Progress in Rainfed Lowland Rice; International Rice Research Institute, Breeding for Submergence Tolerance in Rice in India: Los Baños, CA, USA, 1986; pp. 192-200.

75. Mishra, S.B.; Senadhira, D.; Manigbas, N.L. Genetics of submergence tolerance in rice (Oryza sativa L.). Field Crops Res. 1996, 46, 177-181. [CrossRef] 
76. Mackill, D.J.; Amante, M.M.; Vergara, B.S.; Sarkarung, S. Improved semidwarf rice lines with tolerance to submergence of seedlings. Crop Sci. 1993, 33, 749-753. [CrossRef]

77. Mackill, D.J. Breeding for resistance to abiotic stresses in rice: The value of quantitative trait loci. In Plant Breeding: The Arnel R. Hallauer International Symposium; Lamkey, K.R., Lee, M., Eds.; Blackwell Publication: Ames, IA, USA, 2006; pp. 201-212.

78. Xu, K.N.; Deb, R.; Mackill, D.J. A microsatellite marker and a codominant PCR-based marker for marker-assisted selection of submergence tolerance in rice. Crop Sci. 2004, 44, 248-253.

79. Septiningsih, E.M.; Pamplona, A.M.; Sanchez, D.L.; Neeraja, C.N.; Vergara, G.V.; Heuer, S.; Ismail, A.M.; Mackill, D.J. Development of submergence tolerant rice cultivars: The Sub1 locus and beyond. Ann. Bot. 2009, 103, 151-160. [CrossRef]

80. Sarkar, R.K.; Panda, D. Distinction and characterisation of submergence tolerant and sensitive rice cultivars, probed by the fluorescence OJIP rise kinetics. Funct. Plant Biol. 2009, 36, 222-233. [CrossRef]

81. Neeraja, C.; Maghirang-Rodriguez, R.; Pamplona, A.; Heuer, S.; Collard, B.; Septiningsih, E. A marker-assisted backcross approach for developing submergence-tolerant rice cultivars. Theor. Appl. Genet. 2007, 115, 767-776. [CrossRef] [PubMed]

82. Hasan, M.M.; Rafi, M.Y.; Ismail, M.R.; Mahmood, M.; Rahimd, H.A.; Alam, M.A. Marker-assisted backcrossing: A useful method for rice improvement. Biotechnol. Biotechnol. Equip. 2015, 29, 237-254. [CrossRef] [PubMed]

83. Collard, B.C.Y.; Mackill, D.J. Marker-assisted selection: An approach for precision plant breeding in the 21st century. Philos. Trans. R. Soc. B Rev. 2008, 363, 557-572. [CrossRef]

84. Young, N.D.; Tanksley, S.D. RFLP analysis of the size of chromosomal segments retained around the Tm-2 locus of tomato during backcross breeding. Theor. Appl. Genet. 1989, 77, 353-359. [CrossRef] [PubMed]

85. Das, K.K.; Panda, D.; Sarkar, R.K.; Reddy, J.N.; Ismail, A.M. Submergence tolerance in relation to variable floodwater conditions in rice. Environ. Exp. Bot. 2009, 66, 425-434. [CrossRef]

86. Voesenek, L.A.; Bailey-Serres, J. Flood adaptive traits and processes: An overview. New Phytol. 2015, 206, 57-73. [CrossRef]

(C) 2020 by the authors. Licensee MDPI, Basel, Switzerland. This article is an open access article distributed under the terms and conditions of the Creative Commons Attribution (CC BY) license (http://creativecommons.org/licenses/by/4.0/). 